\title{
ECOLOGICAL ASPECT OF ANTIBIOTIC BATUMIN SYNTHESIS BY PSEUDOMONAS BATUMICI
}

\author{
V.V. Klochko ${ }^{1,2}$, I.I. Lipova ${ }^{1,2}$, N.V. Chuiko ${ }^{1}$ L.V. Avdeeva ${ }^{1}$ \\ ${ }^{1}$ Zabolotny Institute of Microbiology and Virology, NAS of Ukraine, \\ 154 Acad. Zabolotny Str., Kyiv, 03143, Ukraine \\ ${ }^{2}$ National Technical University of Ukraine «I. Sikorsky Kyiv Polytechnic Institute», \\ 37 Prosp. Peremohy, Kyiv, 03056, Ukraine, \\ e-mail:vvklochko@ukr.net
}

The species Pseudomonas batumici, isolated from the rhizosphere of eucalyptus in the humid subtropical zone, is a producer of the polyketide antibiotic batumin with highly selective activity against staphylococci. Batumin biosynthesis operon includes 28 genes or 74151 bp. According to modern notions, the biosynthesis of energy-intensive metabolites, which probably includes batumin, is justified in the case of its multifunctionality for producers. The species P. batumici, as a representative of rhizosphere bacteria, must interact with plants and compete with the surrounding microbiota. Aim. To determine the role of batumin in the ecology of the rhizosphere producer strain P. batumici UCM B-321. Materials and Methods. The batumin producing strain P. batumici UCM B-321 ${ }^{T}$ was obtained from the Ukrainian Collection of Microorganisms. Antibiotic batumin was obtained by fermentation of P. batumici UCM $B$-321. Extraction was carried out from acidified P. batumici fermentation broth by chloroform $(1: 2)$. Chromatographic analysis of fermentation broth obtained after centrifugation was carried out by HPLC using liquid chromatograph Agilent 1200 with mass spectrometric detector Agilent G1956B. Batumin derivatives were obtained after the extraction of the fermentation broth of $P$. batumici using thin layer chromatography (TLC) on silica gel plates (Merck, USA) in the benzene-isopropanol system (5:1). Disc-diffusion method on phytopathogenic test-strains was used for bioautography. Biofilm formation by $P$. batumici strain was studied according to O'Toole by growing strain $B-321$ at $25{ }^{\circ} \mathrm{C}$ for 48 hours in 96-well plates on LB medium. Batumin effect upon bacterial mobility was studied using Volf and Berg method in Petri dishes with $0.5 \%$ semisolid bacterial agar. To research chemotaxis the soil strain Bacillus subtilis IMV B-7023 and the following concentrations of batumin were used: 20, 50, and $150 \mu \mathrm{g} / \mathrm{mL}$. The studies were performed using Tso and Adler method. Results. Growth inhibition zones for phytopathogenic bacteria strains were the following (in mm): Pseudomonas syringae pv. syringae UCM $B-1027^{T}-19 \pm 3$, P. fluorescens IMV $8573-22 \pm 3$, Pectobacterium carotovorum UCM B-1075T $-17 \pm 2$. Activity against Xantomonas campestris pv. campestris UCM B-1049, Clavibacter michiganensis subsp. michiganensis IMV 10, Agrobacterium tumefaciens UCM B-1000 was not detected. Minimum inhibitory concentrations (MIC) in the range from 8 to $64 \mu \mathrm{g} / \mathrm{mL}$ for P. carotovorum UCM B-1075 , Erwinia aroidea IMV 1058, Proteus vulgaris UCM B-905 and P. fuorescens IMV 8573 are hardly comparable with the discovered against staphylococci. TLC analysis of its broth extract revealed five separate compounds with different values of retention factors: $R f_{1}=0.42 ; R f_{2}=0.38 ; R f_{3}=0.31 ; R f_{4}=0.28 ; R f_{5}=0.25$. The main component of extract was batumin, other four substances were present in minor quantities. All found substances had similar absorption maxima with the minimum differences between isomeric forms: descarbamoyl batumin-enol $(\mathrm{Mr}=505, \lambda=226 \mathrm{~nm})$, descarbamoyl batumin-keto $(\mathrm{Mr}=505, \lambda=231 \mathrm{~nm})$, batumin $(M r=548, \lambda=231 \mathrm{~nm})$, batumin-enol $(\mathrm{Mr}=548, \lambda=228 \mathrm{~nm})$ and 17-hydroxy-batumin $(\mathrm{Mr}=550$, $\lambda=229 \mathrm{~nm}$ ). The largest inhibition zone (P. carotovorum UCM B-1075T) was on the third compound placement which represents of batumin, tiny inhibition zones were found around keto and enol form of descarbamoyl batumin. Observation of live bacterial cells in light microscope confirmed a serious disruption of motility in all these bacteria by batumin in the concentration far lower than the MIC for these organisms. Proteus actively moved in the control, but in presence of $10 \mu \mathrm{g} / \mathrm{mL}$ of batumin was almost no growth. The biofilm formation by P. batumici UCM B-321 was stimulated by supplementing batumin into the medium. The stimulation effect by batumin on the biofilm formation was equally strong when the compound was applied in the concentrations of 1 and $10 \mu \mathrm{g} / \mathrm{mL}$. Batumin was not an attractant of the producer strain. However, in one of our experiments batumin has shown the properties of positive 
effector (attractant) for B. subtilis UCM B-7023 strain. Conclusion. The discovered features allow to consider the antibiotic batumin synthesized by P. batumici UCM B-321 as the essential tool for survival and competition of the producer strain in a natural habitat.

Keywords: Pseudomonas batumici, batumin, biofilm formation, antimicrobial activity, phytopathogenic bacteria.

Bacteria of Pseudomonas genus play a vital role in maintaining soil quality, plant yield and ecosystem function. The release of the genome sequence of beneficial Pseudomonas strains has demonstrated the catabolic and metabolic diversity of the soil-borne, nonpathogenic pseudomonads and provided further insight to their potential application in agriculture [1-4]. Most of antibiotic substances produced by the members of this genus were studied from medical application point of view. Only phenazine derivatives, their biological function in producing strain, effect upon phytopathogens, and role in biological control were profoundly studied [5]. Still less is known about these properties of medically used antibiotics, in particular about batumin - polyketide antibiotic produced by Pseudomonas batumici - and its plant-interaction mechanisms. Batumin produced by a saprotrophic Pseudomonas strains has shown high and selective activity against staphylococci [6-8] which is several folds higher than against other test-microorganisms. During many years of intensive study, attention was focused upon biosynthesis of batumin, its chemical structure, perspectives of medical use, but its ecological and physiological role, function in producing strain, mechanism of antimicrobial action (in particular against soil bacteria) remained undiscovered.

Therefore, the aim of our work was to study role of batumin in the ecology of the rhizosphere producer strain P. batumici UCM B-321.

Materials and methods. The batumin producing strain $P$. batumici $\mathrm{UCM} \mathrm{B}-321^{\mathrm{T}}$ was obtained from the Ukrainian Collection of Microorganisms (UCM), Zabolotny Institute of Microbiology and Virology of NAS of Ukraine. Antibiotic batumin was obtained by fermentation of $P$. batumici UCM B-321.

Extraction was carried out from acidified P. batumici culture fluid by chloroform (1:2), extract was evaporated in vacuum and purified using preparative chromatography. Chromatographic analysis of culture fluid obtained after centrifugation was carried out by high performance liquid chromatography (HPLC) using liquid chromatograph Agilent 1200 with mass spectrometric detector Agilent G1956B. Chromatographic system was the following: column SB-C18 (Zorbax $150 \mathrm{~mm}$ x $4.6 \mathrm{~mm}$ x $3.5 \mu \mathrm{m}$ ) with nonpolar octadecyl group (reversible phase), mobile phase - $\mathrm{ACN}: \mathrm{H}_{2} \mathrm{O}(55: 45)$, temperature of the column was $30{ }^{\circ} \mathrm{C}$, flow rate $1 \mathrm{~mL} / \mathrm{min}$, isocratic regime, injection volume $5 \mu \mathrm{L}$. Ionization method was atmospheric pressure chemical ionization (APCI), positive and negative modes.

Batumin derivatives were obtained after the extraction of the fermentation broth of $P$. batumici using thin layer chromatography (TLC) on silica gel plates (Merck, USA) in the benzene-isopropanol system $(5: 1)$. Identification and calculation of retention factor (Rf) of spots was held in iodine vapor. Disc-diffusion method on phytopathogenic test-strains was used for bioautography. Inhibition zones were measured after 24 hours. Physicochemical characterization of the obtained compounds was performed by measuring the absorption spectra. Molecular weights were identified using LC/MS method (Agilent 1200, USA).

The minimal inhibitory concentration (MIC) was established by titration using the test-strains from the UCM: Agrobacterium tumefaciens UCM B-1000, Arthrobacter globiformis UCM Ac-661, Bacillus pumilus UCM B-913, Bacillus cereus UCM B-908, Brevundimonas diminuta UCM B-914, Micrococcus luteus UCM Ac632, Mycobacterium smegmatis UCM B-917, Pectobacterium carotovorum UCM B-1075', Proteus vulgaris UCM B-905, Pseudomonas syringae pv. syringae UCM B- $1027^{\mathrm{T}}$, Xantomonas campestris pv. campestris UCM B-1049 and Erwinia aroidea IMV 1058, Pseudomonas fluorescens IMV 8573, Clavibacter michiganensis subsp. michiganensis IMV 10, from Department of phytopathogenic bacteria, IMV NASU. Strains of $P$. vulgaris UCM B-905 and $X$. campestris pv. campestris UCM B-1049 were used for study of immobilizing activity of batumin.

Biofilm formation by $P$. batumici UCM B-321 strain was studied according to O'Toole [9] by growing strain B-321 at $25^{\circ} \mathrm{C}$ for 48 hours in 96well plates on LB medium. Aliquots of 1 and $10 \mu \mathrm{g}$ 
batumin $/ \mathrm{mL}$ were added to $0.25 \mathrm{~mL}$ per well of the cell suspensions $\left(5 \times 10^{7}\right.$ cells $\left./ \mathrm{mL}\right)$. Biofilms were stained by $0.1 \%$ solution of gentian violet EF (BioMerieux, France) added in the amount of $0.1 \mathrm{~mL}$ per well. Then the microplate photometer Multiskan FC (ThermoFisherScientific, USA) was used to record the density at $540 \mathrm{~nm}$.

Batumin structure was digitized in Discovery Studio 4.0 Client (http://accelrys.com). Molecular docking was performed by LibDock algorithm implemented in Discovery Studio 4.0 Client [10].

Batumin effect upon bacterial mobility was studied using Volf and Berg method in the Petri dishes with $0.5 \%$ semisolid bacterial agar [11]. The latter contained $32 \mu \mathrm{g} / \mathrm{mL}$ of batumin (MIC for P. vulgaris UCM B-905) or 25 and $10 \mu \mathrm{g} / \mathrm{mL}$ of antibiotic. Control assay did not contain batumin. Inoculated into $5 \mathrm{~mm}$ well in the center of Petri dish with $0.5 \%$ semi-solid nutrient agar, P. vulgaris UCM B-905 spread over agar surface in so far Petri dish rims during overnight incubation at $37{ }^{\circ} \mathrm{C}$.

The immobilization activity of batumin upon the living bacterial cells was also studied in the light microscope LOMO MikMed-1 using the method of "hanging drop". Subbacteriostatic concentrations of batumin were added to saline with bacterial suspension; the microscopy was performed after 15-20 min. The control sample did not contain the antibiotic.

To research chemotaxis, the soil strain Bacillus subtilis UCM B-7023 [12] and the following concentrations of batumin were used: 20,50 , and $150 \mu \mathrm{g} / \mathrm{mL}$. The studies were performed using the method described in the literature [13].

Results. Analysis of complete genome sequence of $P$. batumici UCM B-321 data confirmed its capacity to survive in a complex rhizosphere environment amongst multiple bacterial and fungal competitors [10]. Considering that batumin producing strain was isolated from the rhizosphere, we made an attempt to evaluate batumin effect against soil saprophytes or phytopathogens. On the first stage of the study, we determined the antagonistic properties of $P$. batumici against phytopathogenic bacteria (Fig. 1).

Zones of growth inhibition for phytopathogenic bacteria strains were following (in $\mathrm{mm}$ ): $P$. syringae pv. syringae UCM B- $1027^{\mathrm{T}}-19 \pm 3$, P. fluorescens IMV $8573-22 \pm 3$, P. carotovorum UCM $\mathrm{B}-1075^{\mathrm{T}}-17 \pm 2$. Activity against $X$. campestris pv. campestris UCM B-1049, C. michiganensis subsp. michiganensis IMV $10_{2}$, A. tumefaciens UCM B-1000 was not detected. The next step was to determine the MIC of batumin for a wide range of soil and phytopathogenic bacteria (Table 1).

MIC in the range from 8 to $64 \mu \mathrm{g} / \mathrm{mL}$ for Pectobacterium, Erwinia, Proteus and Pseudomonas are hardly comparable with the discovered against staphylococci [6], however the results allow us to consider the antibiotic to be responsible for the competitiveness of the strain $P$. batumici $\mathrm{UCM}$ B-321 in nature due to its possibility of inhibition of those phytopathogens in soil habitat.

It was shown that the operon responsible for batumin biosynthesis is significant in its size and contains 28 coding genes [10]. Besides, the antibiotic molecule is multifunctional and capable of forming isomeric forms [14]. Based on this, we made an assumption about the presence of a number of batumin derivatives with possible antibiotic activity in the fermentation broth of P. batumici UCM B-321.

The next stage of our work was the study of batumin isomers or derivatives produced by strain P. batumici UCM B-321. TLC analysis of its broth extract revealed five separate compounds with different values of retention factors: $\mathrm{Rf}_{1}=0.42$; $\mathrm{Rf}_{2}=0.38 ; \mathrm{Rf}_{3}=0.31 ; \mathrm{Rf}_{4}=0.28 ; \mathrm{Rf}_{5}=0.25$. Bioautography, physicochemical characterization and identification were performed for these 5 substances (Table 2).

The main component of extract was batumin, other four substances were present in minor quantities. The data about absorption spectrums

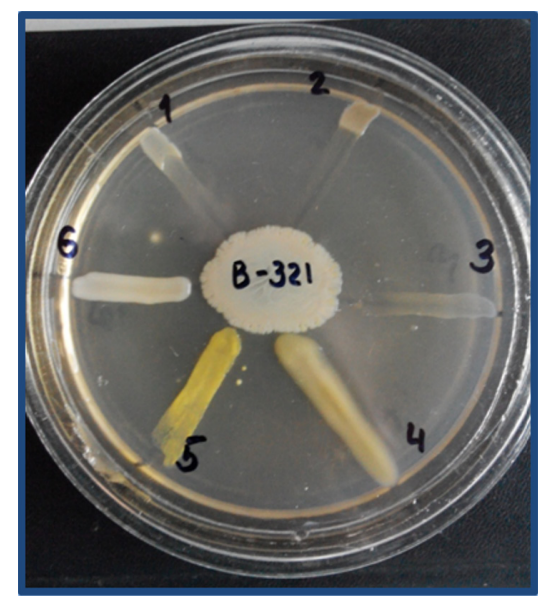

F i g. 1. Antagonism of $P$. batumici B-321 against phytopathogenic bacteria:

1 - P. syringae pv. syringae UCM B-1027 ${ }^{\mathrm{T}}$; 2 - P. fluorescens IMV 8573; 3 - P. carotovorum UCM B-1075' 4 -X. campestris pv. campestris UCM B-1049; 5 - C. michiganensis subsp. michiganensis IMV $10 ; 6-A$. tumefaciens UCM B-1000 
Table 1

Batumin antibacterial activity against microorganisms of different taxonomic groups

\begin{tabular}{|l|r|c|}
\hline No. & Species, strain & MIC $\boldsymbol{\mu g} / \mathbf{m L}$ \\
\hline 1 & Agrobacterium tumefaciens UCM B-1000 & $>256$ \\
\hline 2 & Arthrobacter globiformis UCM Ac-661 & $>256$ \\
\hline 3 & Bacillus pumilus UCM B-913 & 256 \\
\hline 4 & Bacillus cereus UCM B-908 & 64 \\
\hline 5 & Brevundimonas diminuta UCM B-914 & 256 \\
\hline 6 & Clavibacter michiganensis subsp. michiganensis IMV 10 & 10 \\
\hline 7 & Erwinia aroidea IMV 1058 & $>256$ \\
\hline 8 & Micrococcus luteus UCM Ac-632 & 64 \\
\hline 9 & Pectobacterium carotovorum UCM B-1075 & 32 \\
\hline 10 & Proteus vulgaris UCM B-905 & 64 \\
\hline 11 & Pseudomonas fluorescens IMV 8573 & 25 \\
\hline 12 & Pseudomonas syringae pv. syringae UCM B-1027 & $>256$ \\
\hline 13 & Xanthomonas campestris pv. campestris UCM B-1049 & 8 \\
\hline 14 &
\end{tabular}

Table 2

Characterization of extracted batumin derivatives

\begin{tabular}{|l|c|c|c|c|c|}
\hline \multirow{2}{*}{ Characteristics } & \multicolumn{5}{|c|}{ Substance* No. } \\
\cline { 2 - 6 } & I & II & III & IV & V \\
\cline { 2 - 6 } & Descarbamoyl & $\begin{array}{c}\text { Descarbamoyl } \\
\text { batumin (keto) }\end{array}$ & Batumin (keto) & Batumin (enol) & $\begin{array}{c}\text { 17-hydroxy- } \\
\text { Batumin }\end{array}$ \\
\hline Molecular weight & $505^{*}$ & 505 & 548 & 548 & 550 \\
\hline $\begin{array}{l}\text { Absorption spectra } \\
\text { maximum }\end{array}$ & 226 & 231 & 231 & 228 & 229 \\
\hline
\end{tabular}

Legend: ${ }^{*}$ - an assumption.

and molecular weights allowed us to make few assumptions about the nature of found derivatives.

All found substances had similar absorption maxima with the minimum differences between isomeric forms. The TLC method allows to separate keto and enol forms of the substances. So substance III was identified as batumin, the substance IV with the same molecular weight was considered to be its enol isomer. In earlier studies the ability of keto-enol tautomerization of batumin molecule was described [14] and batumin derivative [8] descarbamoyl batumin with molecular weight 505 was found.

We delve deeper into the chemical properties and predicted that descarbamoyl batumin should have the enol form (I) or keto (II), due to the presence of the same area in the molecule that is responsible for tautomerization and the obtained results proved that hypothesis. The fifth compound did not have any isomers which provided the evidence of the possible place of oxidation - tautomerization area. Based on study of kal/bat gene cluster [15] and the results of physicochemical characterization we suggest that it was 17-hydroxybatumin - predecessor of batumin in biosynthesis pathway, according to the authors. Bioautography results correlated with MIC results for batumin against phytopathogenic test-strains and showed the most significant inhibition against $P$. carotovorum $\mathrm{UCM}$ B- $1075^{\mathrm{T}}$ (Fig. 2).

The largest growth inhibition zone was on the third compound placement which represents keto form of batumin, tiny inhibition zones were found around keto and enol form of descarbamoyl batumin. Those results (for the present qualitative but not quantitative) suggest that batumin in keto form plays pivotal role in competitiveness for producing strain in soil habitat, whereas the role of other derivatives is probably not important or less essential.

One more remarkable batumin peculiarity as a possible factor of competitive struggle in nature was established using molecular docking method which is effective when the chemical structure of molecule is known but the target of its action is still unknown. Chemical structure of batumin was searched for affinity matches through PharmaDB database containing around 140,000 
pharmacophore models [16, 17].

Molecular docking method has shown the possible batumin influence on protein $\operatorname{Mot} B$. This protein is the component of flagella of Gramnegative bacteria and forms the ion-conducting complex which generates the turnover moment putting the flagella and, accordingly, the bacteria in motion. Depending on external influence on MotB protein the direction of flagella turnover

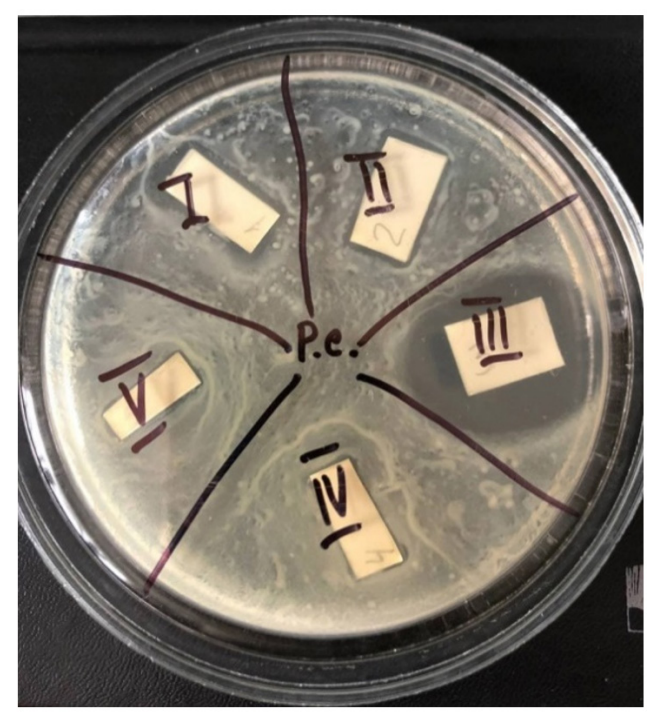

F i g. 2. Bioautography of batumin and its derivatives on $P$. carotovorum $\mathrm{UCM}$ B-1075' I - Descarbamoyl batumin (enol); II - Descarbamoyl batumin (keto); III - Batumin (keto); IV - Batumin (enol); V - 17-hydroxy-batumin may be changed, or it may completely stop. Batumin bounds specifically to the amino acids of the conserved motif of MotB (Fig. 3) that was predicted as the binding site between MotB and peptidoglycan.

It was shown that batumin molecule may form a complex with the protein $M o t B$. Batumin relates to protein by its amino group forming 6 bonds 3 hydrogenous and 3 hydrophobic. By binding to these amino acids, batumin may destroy the flagellar motor and leave cells of the competitor bacteria immotile. In order to experimentally verify these data and to check the possible effect of batumin on bacterial motility, P. vulgaris was used as the most motile organism, MIC for which was $32 \mu \mathrm{g} / \mathrm{mL}$ (Fig. 4).

Inoculated into the well in the center of Petri dish with semi-solid nutrient agar, P. vulgaris spread over agar surface in so far Petri dish rims. Supplementing the nutrient agar with $10 \mu \mathrm{g} / \mathrm{mL}$ of batumin reduced the spread zone to $25 \mathrm{~mm}$, and higher concentrations of batumin $(25 \mu \mathrm{g} / \mathrm{mL})$ reduced its spread for $10 \mathrm{~mm}$. Hence, we observed the converse connection between subbacteriostatic batumin concentrations and Proteus spreading throughout the dish surface.

Observation of live bacterial cells in light microscope confirmed a serious disruption of motility in $P$. vulgaris UCM B-905 by batumin in concentration far lower than the MIC for these organisms. Proteus actively moved in the control,

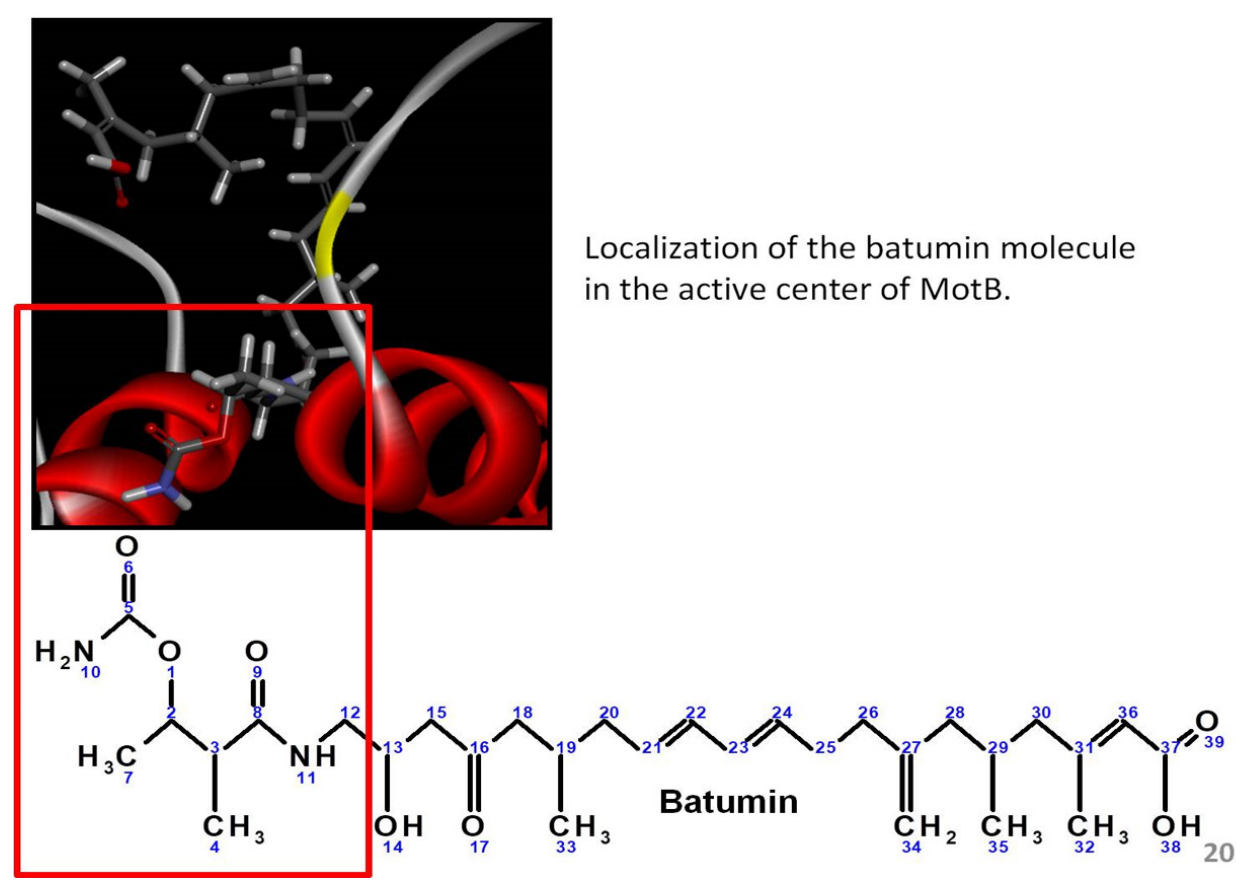

F i g. 3. Docking of batumin to peptidoglycan binding site of MotB flagellar motor-switch protein 

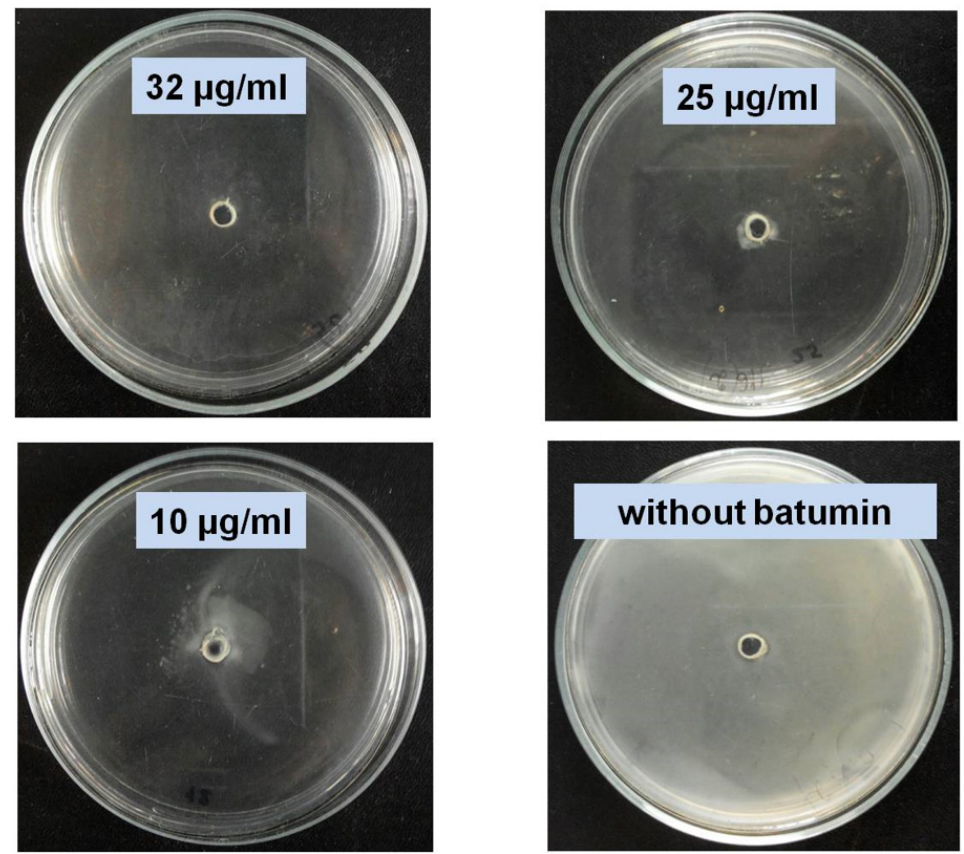

F i g. 4. Batumin effect on P. vulgaris UCM B-905

but in the presence of $10 \mu \mathrm{g} / \mathrm{mL}$ of batumin the active movement was absolutely absent. The same was observed for $X$. campestris pv. campestris UCM B-1049 (MIC $300 \mu \mathrm{g} / \mathrm{mL}$ ): in presence of 75 $\mu \mathrm{g} / \mathrm{mL}$ of batumin - the concentration four times lower - antibiotic completely inhibited the active movement of this microorganism.

About 95-99 \% of microorganisms are present in nature in biofilm status. The biofilm formation at the plant roots surface and active functioning of bacteria as the biofilm members ensure the exchange of nutrient substances with the plant, synthesis of antimicrobial substances which protect the plants from pathogens and other useful effects [18].

Our experiments have shown that $P$. batumici UCM B-321 is capable of biofilm formation just as the other Pseudomonas species (Fig. 5).

The biofilm formation by $P$. batumici UCM B-321 was stimulated by supplementing batumin into the medium. The stimulation effect of batumin on the biofilm formation was equally strong when the compound was applied in the concentrations of 1 and $10 \mu \mathrm{g} / \mathrm{mL}$. In both cases, the rate of biofilm formation uplifted with a statistical reliability

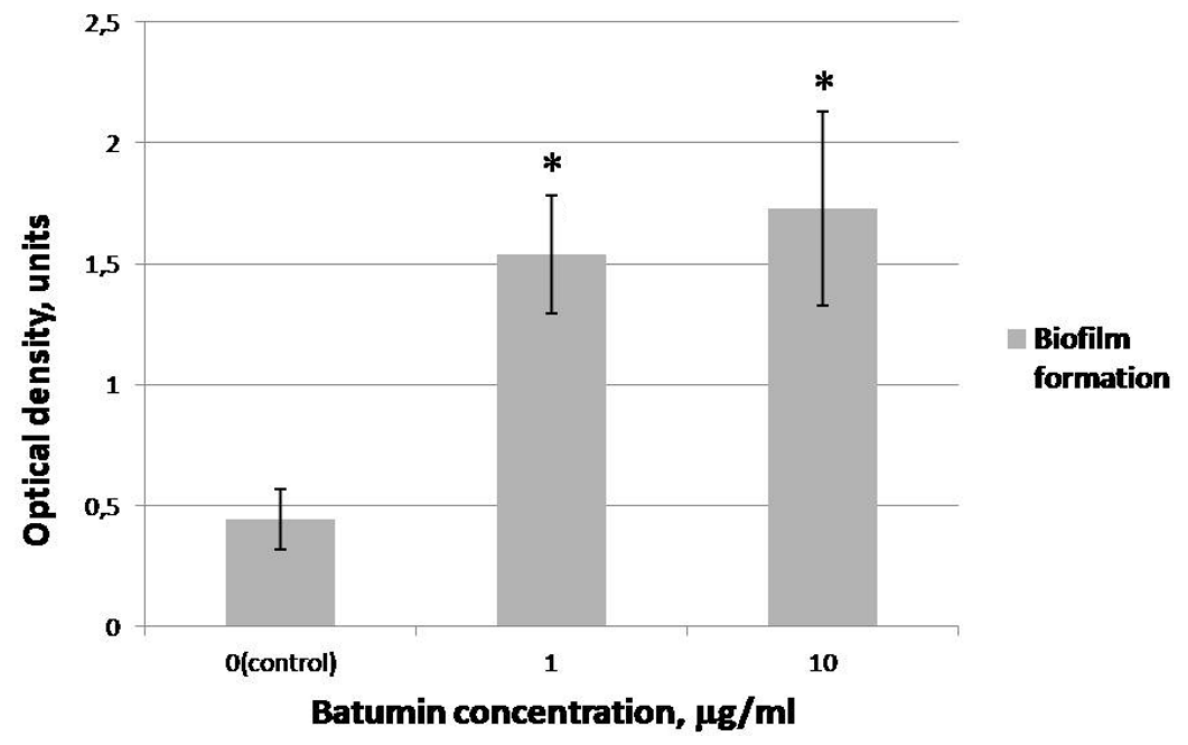

F i g. 5. Stimulation of biofilm formation in P. batumici UCM B-321: marked columns (*) are significantly differ from the control at $P<0.05$ 
$(P<0.01)$. It is known that the phenazine antibiotics widespread in pseudomonads play an important role in biofilm formation which occurs with the QS-systems participation [5, 19]. It is possible to suppose that batumin also plays regulatory and probably functional role in biofilm formation by P. batumici UCM B-321 strain as well.
Data presented above concern inhibition of some bacterial groups or species by batumin. At the same time many soil inhabitants, for example spore-forming bacilli, are weakly susceptible or not at all susceptible to this antibiotic. However, in one of our experiments batumin has shown the properties of positive effector (attractant) for B. subtilis UCM B-7023 strain (Fig. 6).
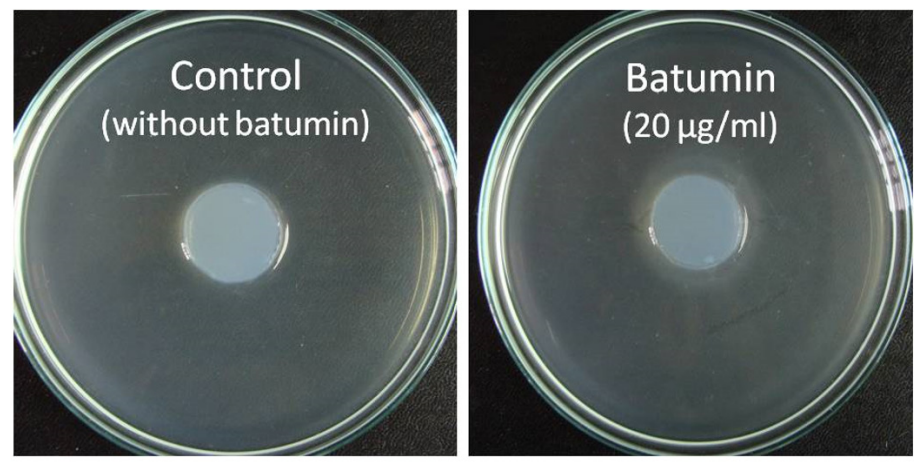

\section{F i g. 6. Chemotaxis of $B$. subtilis UCM B-7023 (effector - batumin)}

The inversely proportional dependence between increasing of batumin concentration and its attractive effect has been observed. The width of chemotaxis rings at batumin concentration $20 \mu \mathrm{g} / \mathrm{mL}$ was $6.0 \pm 0.6 \mathrm{~mm}$, but at $150 \mu \mathrm{g} / \mathrm{mL}$ it was only $3.7 \pm 0.3 \mathrm{~mm}$. The nature of this phenomenon is still unclear.

Discussion. Genome analysis of $P$. batumici UCM B-321 confirmed that it is the rhizospheric microorganism armed with all necessary instruments for survive in the environment. P. batumici UCM B-321 is relative and similar in its properties to fluorescent pseudomonads but is not capable of producing pseudobactin - the fluorescent pigment typical for representatives of this group (which is confirmed both by genome sequence analysis and phenotypic study). The generally accepted (but seldom experimentally confirmed) notion that antibiotics are the instrument of competition between microorganisms in the environment is confirmed by data presented in this work.

We have shown that batumin and its minor isomers or derivatives isolated from fermentation broth of $P$. batumici UCM B-321 (and present in enol or keto forms owing to tautomeria effect) has shown antimicrobial effect against some phytopathogens. Inhibiting growth of P. carotovorum UCM B-1075 ${ }^{\mathrm{T}}$, P. syringae pv. syringae UCM B-1027 ${ }^{\mathrm{T}}$, P. vulgaris UCM B-905, M. smegmatis UCM B-917 batumin and its derivatives may play an essential role in highly competitive environmental niches such as soil and the plant rhizosphere.

At the same time genome of this species contains the genes encoding the synthesis of phenazine1-carboxylic acid which we have isolated before from P. batumici UCM B-321 and studied its effect against bacteria and fungi [20]. According to data obtained in the recent years the phenazines importance for the producing strains is not limited by their antimicrobial activity. They also act as important regulators of gene expression and excite other effects including the biofilm formation [5, 19]. In our experiments phenazine-1-carboxylic acid stimulated biofilm formation in $P$. batumici UCM B-321 [20].

Similar to phenazine-1-carboxylic acid produced by few species of pseudomonads, batumin stimulated the biofilm formation in P. batumici UCM B-321. Batumin influence upon the biofilm formation (much more intensive than the same of phenazine-1-carboxylic acid) is undoubtedly important for antibiotic producing strain and its biochemical or genetic mechanisms need detailed study and analysis. The evolutionary hypothesis maintains that the biosynthesis of energetically expensive metabolites in microbial cells is justified only if they are multifunctional. Probably this conformity to natural laws may be applied to batumin with its unique chemical structure and abundance of isomers and derivatives (including the stereoisomers) whose role in P. batumici UCM B-321 biology is still unknown. 
The notion that antibiotics are the competition instruments between microorganisms was supplemented by interesting new data which we obtained using the results of the molecular docking techniques. It was shown that batumin is able to bind to bacterial motB motor switch protein [21]. The fast immobilization of motile Gramnegative bacteria by batumin has been confirmed experimentally. Motility is the necessary factor of plant colonization, so this effect upon many bacterial species may play the essential ecological role for P. batumici UCM B-321.

Discovery of the effect of batumin on bacterial motility opens the perspectives for a broader use of this antibiotic. In relation to many Gram-negative medicinal and agricultural pathogens batumin acts as a "non-lethal weapon". The target bacteria do not die, they simply cannot act as pathogens in the place of application of small doses of the antibiotics. Probably it may be used in future in medicine, veterinary or for plant protection after further investigations.

Conclusion. The discovered features allow to consider the antibiotic batumin synthesized by P. batumici UCM B-321 as the essential tool for survival and competition of the producer strain in a natural habitat.

Acknowledgements. This work was performed using the equipment of the Center for Collective Usage of NAS of Ukraine, Zabolotny Institute of Microbiology and Virology, NAS of Ukraine.

The authors are grateful to Prof. O.A. Kiprianova for a great deal of support and assistance in discussing the results and preparing this article and Prof. O.M. Reva (Centre of Bioinformatics and Computational Biology, University of Pretoria) for the provided molecular docking data of the batumin molecule.

\section{ЕКОЛОГІЧНА РОЛЬ АНТИБІОТИКА БАТУМІНА, СИНТЕЗОВАНОГО PSEUDOMONAS BATUMICI}

\author{
В.В. Клочко ${ }^{1,2}$, I.I. Ліпова ${ }^{1,2}$, \\ Н.В. Чуйко ${ }^{1}$, Л.В. Авдєєва ${ }^{1}$
}

${ }^{1}$ Інститут мікробіології і вірусологіі ім. Д.К. Заболотного НАН Украӥни, вул. Академіка Заболотного, 154, Київ, 03143, Украӥна

${ }^{2}$ Національний технічний університет Украӥни «Київський політехнічний інститут

імені Ігоря Сікорського», пр. Перемоги, 37, Київ, 03056, Україна

\section{Резюме}

Вид Pseudomonas batumici, виділений з ризосфери евкаліпта у вологій субтропічній зоні, $\epsilon$ продуцентом полікетидного антибіотика батуміну з високою селективною активністю щодо стафілококів. Згідно наших даних повного сиквенсу геному штаму P. batumici УКМ В-321, за біосинтез батуміну відповідає значна частина геному, яка містить 28 генів або близько 70000 пар нуклеотидів. Згідно сучасних уявлень, біосинтез енергетично затратних метаболітів, до яких, ймовірно, відноситься і батумін, виправдовує себе у випадку своєї поліфункціональності для продуцентів. Оскільки вид P. batumici є представником ризосферних бактерій - актуальним $є$ дослідження ролі батуміну у взаємодії з рослинами та оточуючою мікробіотою. Мета. Встановити роль батуміну в екології ризосферного штаму-продуцента P. batumici УКМ В-321. Методи. Предметом дослідження був антибіотик батумін, синтезований штамом P. batumici УКМ В-321 та близькі йому за структурою мінорні компоненти, утворювані в процесі біосинтезу. Культуральну рідину штаму, отриману в умовах глибинного культивування, екстрагували хлороформом (1:2). Похідні батуміну отримували методом тонкошарової хроматографії, використовуючи силікагельні пластини (Merck, USA) в системі бензол:ізопропанол - 5:1; проявник - пари йоду. Аналіз отриманих сполук та визначення їх молекулярних мас проводили методом високоефективної рідинної хроматографії (Agilent $1200)$ із застосуванням мас-спектрометричного детектору (Agilent G1956B): колонка SB-C18 (Zorbax), рухома фаза - ацетонітрил:вода (55:45), температура колонки $-30{ }^{\circ} \mathrm{C}$, швидкість потоку 1 мл/хв, ізократичний режим, інжекція - 5 мкл; іонізація методом АРСІ. Для біоавтографії отрима- 
них сполук і визначення мінімальної пригнічуючої концентрації (МПК) використовували тест-штами бактерій з Української колекції мікроорганізмів та відділу фітопатогенних бактерій IMВ НАН України. Біоплівкоутворення вивчали методом O’Toole на поживному середовищі LB. Як барвник використовували генціанвіолет (BioMerieux, France). Для оцінки рівня утворення біоплівки штамом P. batumici УКМ В-321 застосовували фотометричне визначення за допомогою сканеру для планшет Multiskan FC (Thermo Fisher Scientific, USA); довжина хвилі 540 нм. Вплив антибіотика батуміну на рухливість бактерій вивчали на чашках Петрі 3 напіврідким агаром, додаючи різні концентрації антибіотика: 10, 25 і 32 мкг/мл. Як тест-штам використовували Proteus vulgaris УКМ В-905. Додатково використовували метод світлової мікроскопії, препарат «висяча крапля» та світловий мікроскоп «Мікмед-1». Хемотаксис вивчали методом Тso i Adler, вимірюючи зони на чашках Петрі. Ефектором слугував антибіотик батумін в концентраціях 20, 50 і 150 мкг/мл; тест-штам Bacillus subtilis УКМ В-7023. Результати. Встановлено, що за своїми антагоністичними властивостями штам P. batumici УКМ В-321 виявився високо активним до багатьох сапротрофних і фітопатогенних бактерій, зокрема Pectobacterium carotovorum УКМ В-1075' ${ }^{\mathrm{T}}$ Pseudomonas syringae pv. syringae УКМ В-1027 ${ }^{\mathrm{T}}$ та P. fluorescens IMB 8573, зони затримки росту яких становили 17-22 мм. Мінімальна пригнічуюча концентрація батуміну щодо різних фітопатогенних бактерій коливалася від 8 (P. carotovorum УКМ В-1075 ${ }^{\mathrm{T}}$ ) до 256 (Clavibacter michiganensis subsp. michiganensis IMV 102) мкг/ мл. 3 екстракту культуральної рідини P. batumici

1. Bernd H, Rehm A. Pseudomonas. Model organism, pathogen, cell factory. Weinheim: WILEYVCH Verlag GmbH \& Co. KgaA; 2008.

2. Kahlon RS. Pseudomonas: molecular and applied biology. Springer International Publishing Switzerland; 2016.

3. Weller D. Pseudomonas biocontrol agents of soil-born pathogens: looking back over 30 years. Phytopathology. 2007; 97:250-256. https://doi. org/10.1094/PHYTO-97-2-0250_

4. Mercado-Blanco J, Bakker P. Interactions between plants and beneficial Pseudomonas spp.: exploiting bacterial traits for crop protection. Antonie van Leeuwenhoek. 2007; 92(4):367-89.
УКМ В-321 було виділено, охарактеризовано за фізико-хімічними та антибіотичними властивостями похідні батуміну. Окрім батуміну (молекулярна маса $\mathrm{Mr}=548$, максимум спектру поглинання $\lambda=213$ ) в культуральній рідині виявлено: енол дезкарбамоїлбатуміну (прогнозована $\mathrm{Mr}=505$, $\lambda=226)$, кетодезкарбамоїлбатумін $(\mathrm{Mr}=505, \lambda=231)$, енол батуміну ( $\mathrm{Mr}=548, \lambda=228)$ та 17 -гідроксибатумін $(\mathrm{Mr}=550, \lambda=229)$. Найбільш антибіотично активною сполукою виявився батумін. Значно менш активними виявилися енол дезкарбамоїлбатуміну та кетодезкарбамоїлбатумін. Методом молекулярного докінгу було розраховано та експериментально підтверджено вплив батуміну на білок $\operatorname{Mot} B$, який є складовою частиною джгутиків грамнегативних бактерій і відповідає за їх рухливість. Встановлено, що за концентрації батуміну 10 мкг/мл відбувалось гальмування повзучого росту Proteus vulgaris УКМ В-905, а при 32 мкг/мл антибіотика повзучий ріст $P$. vulgaris УКМ В-905 був повністю відсутнім. Про екологічну роль батуміну засвідчував той факт, що штам-продуцент батуміну P. batumici УКМ В-321 був здатний утворювати біоплівку, а антибіотик у концентрації 1 i 10 мкг/мл стимулював цей процес. В той же час, за концентрації 20 мкг/мл він виступав позитивним ефектором (атрактантом) для грунтового штаму B. subtilis УКМ В-7023. Висновки. Встановлені особливості дозволяють розглядати утворюваний $P$. batumici УКМ В-321 антибіотик батумін як суттєвий інструмент виживання і конкурентної боротьби штама-продуцента в природних умовах.

Ключові слова: Pseudomonas batumici, батумін, біоплівкоутворення, антимікробна активність, фітопатогенні бактерії.

https://doi.org/10.1007/s10482-007-9167-1

5. Chincholkar S, Thomashow L. Microbial phenazines: biosynthesis, agriculture and health. Springer-Verlag Berlin Heidelberg; 2013.

6. Klochko VV, Kiprianova EA, Churkina LN, Avdeeva LV. [Antimicrobial spectrum of atibiotic batumin]. Microbiol Z. 2008; 70(5):41-46. Russian.

7. Churkina LN, Vaneechoutte M, Kiprianova EA, Perunova NB, Avdeeva LV, Bukharin OV. Batumin - a selective inhibitor of staphylococci reduces biofilm formation in methicillin resistant Staphylococcus aureus. OJMM. 2015; 5(4):5159. http://dx.doi.org/10.4236/ojmm.2015.54024_ 
8. Kiprianova EA, Klochko VV, Zelena LB, Churkina LN, Avdeeva LV. Pseudomonas batumici sp. nov., the antibiotic-producing bacteria isolated from soil of the Caucasus Black sea coast. Mikrobiol Z. 2011; 73(5):3-8.

9. O'Toole G, Kaplan H, Kolter R. Biofilm formation as microbial development. Ann Rev Microbiol. 2000; 54:49-79. https://doi.org/10.1146/ annurev.micro.54.1.49

10. Klochko VV, Zelena LB, Kim JY, Avdeeva LV, Reva ON. Prospects of a new antistaphylococcal drug batumin revealed by molecular docking and analysis of the complete genome sequence of the batumin-producer Pseudomonas batumici UCM B-321. International Journal of Antimicrobial Agents. 2016; 47(1):56-61. https://doi. org/10.1016/j.ijantimicag.2015.10.006

11. Wolfe AJ, Berg HC. Migration of bacteria in semi-solid agar. Proc Natl Acad Sci. USA. 1989; 86(18):6973-6977. https://doi.org/10.1073/ pnas.86.18.6973

12. Patent of Ukraine №54923 A. [Strain of bacteria Bacillus subtilis for bacterial fertilizer obtaining for plant growing]. Kurdish IK, Roy AO. Published in 2003. Bul. №3. Ukrainian.

13. Tso W, Adler J. Negative chemotaxis in Escherichia coli. J Bacteriol. 1974; 118(2):560-576. doi: 10.1128/JB.118.2.560-576.1974.

14. Klochko VV. Biosynthesis and properties of antibiotic batumin. Biotechnologia Acta. 2014; 7(6):46-50. https://doi.org/10.15407/biotech7.06.046

15. Mattheus W, Gao LJ, Herdewijn P, Landuyt B, Verhaegen J, Masschelein J, Volckaert G, Lavi- gne R. Isolation and purification of a new kalimantacin/batumin-related polyketide antibiotic and elucidation of its biosynthesis gene cluster. Chem Biol. 2010; 17(2):149-59. https://doi. org/10.1016/j.chembiol.2010.01.014

16. Diller DJ, Merz KM Jr. High throughput docking for library design and library prioritization. Proteins. 2001; 43(2):113-124. https://doi.org/10.1002/1097-0134(20010501) 43:2\%3C113::aid-prot1023\%3E3.0.co;2-t_

17. Muntha P. Drug discovery \& development. Journal of Pharmacy and Pharmaceutical Sciences. 2016; 5(1):135-142.

18. Nikolaev YA, Plakunov VK. [Biofilm - "City of Microbes" or an analogue of multicellular organisms?]. Microbiologia. 2007; 76 (2):149-163. Russian.

19. Maddula V, Pierson E, Pierson L. Altering the ratio of phenazines in Pseudomonas chlororaphis (aureofaciens) strain 30-84: effects on biofilm formation and pathogen inhibition. J Bacteriol. 2008; 190 (8):2759-2766. https://doi. org/10.1128/JB.01587-07

20. Klochko VV, Zagorodnya SD, Reva ON. Genes encoding synthesis of phenazine-1-carboxylic acid in Pseudomonas batumici. Biotechnologia Acta. 2016; 9(5):45-53. https://doi.org/10.15407/ biotech9.05.045

21. Roujeinikova A. Crystal structure of the cell wall anchor domain of MotB, a stator component of the bacterial flagellar motor: implications for peptidoglycan recognition. Proc Natl Acad Sci. USA. 2008; 105(30):10348-10353. https://doi org/10.1073/pnas.0803039105

Received 28.02.2021 